UDK: 821.511.141.09-3 Бодор А. DOI: https://doi.org/10.18485/25bghun.2021.ch16

\title{
BÁNYAI ÉVA
}

Bukaresti Egyetem, Idegen Nyelvek és Irodalmak Kara, Hungarológia, Judaisztika és Romológia Intézet, Hungarológia Csoport

\section{A hatalmi terek változatai Bodor Ádám prózájában ${ }^{1}$}

\begin{abstract}
Összefoglaló
Írásomban azt vizsgálom, milyen változatai vannak a hatalom-konstrukcióknak Bodor Ádám prózájában a Sinistra körzettől a Verhovina madarain át a Seholig, az elvont diktatúrareprezentáció mindent uraló hatalmától a plurális, megfoghatatlan hatalomtereken át a bőr alatt rejlő, pórusokon át ki- és beszivárgó hatalomig. Vizsgálódásomat nem kerüli el Az érsek látogatásában megképzett átmeneti terek hatalmi diskurzusa sem, de a legfrissebb kortárs vírustapasztalat is szóba kerül.
\end{abstract}

Kulcsszavak: kortárs magyar próza, Bodor Ádám, hatalom.

2019 tavaszán jelent meg Bodor Ádám legújabb novelláskötete, a Sehol (Bodor 2019). Ez a kötet mozgósítja a korábbi prózakötetek trópusait, amelyek a mindent behálózó hatalom látens jelenléte vagy épp jelen nem léte, hiánya, a köztesség térképzetének hálója, az időtlenség alakzatai, az elhallgatás és a másság/idegenség csomópontjai köré formálódnak. Ugyanakkor megjelent a kötetben egy elmozdulás, új hangnem/stílus, amely többekből (kritikusokból, olvasókból) némi ellenérzést váltott ki (lásd pl. Szolláth, 2019).

\footnotetext{
${ }^{1}$ Jelen írásomban felhasználtam a bibliográfiában is jelzett, Bodor Ádám prózájáról korábban megjelent könyveim és folyóiratcikkem egyes részleteit is.
} 
1.

Erre a mindenkori elmozdulásra, eltolódásra hívnám fel a figyelmet: hogyan mozdul ki a Bodor-próza a hatalmi elvárások (legyen az politikai vagy olvasói/kritikusi pozíció) hálózatából. Ezzel a mostani gesztusával lényegében visszakanyarodik a kezdetekhez, a legelső írásainak a szintén eltérő, a többi prózaíróétól elkülönböződő hangneméhez, stílusához, az elvárások negligálásához. Több szempontról lehet itt szó: a hatvanas-hetvenes években, Bodor Ádám indulásakor is legalább két ,igény” volt, egyrészt az irodalompolitikát „csinálók” részéről, ne felejtsük el a korszakot, amely nincs is olyan messze, könnyü párhuzamokat találni akár kurrens folyamatokkal is. Bodor Ádám a hatvanas évek közepén kezdett írni a korabeli Romániában, '69-ben jelent meg az első kötete ( $A$ tanú címmel). Egyrészt a totalitárius hatalmi rendszer részéről létezett egy igény, hogy az írók az újonnan kialakuló, megszilárduló kommunista szellemiség elvárásait elégítsék ki (már az első kötete megjelenése előtt, pusztán a folyóiratpublikációk alapján készült egy kritika Bodor novelláiról, hogy ő a magánzó, a magáníró, ami akkor akár egy feljelentés erejével bírt). Másrészt pedig ott volt a kisebbségideológiai alapon megképződött neotranszilvanista kánon, amely az irodalmi, esztétikai tapasztalatot a regionális nemzeti identitás megörzésének rendelte (volna) alá (lásd pl. Szirák 2000).

Bodor Ádám első írásainak a pátoszmentességével, szikár nyelvezetével, ironikus hangnemével is szembement a neotranszilvanista kánon elvárásaival: a novellákban, elbeszélésekben nyoma sincs az anyanyelvmentés és identitásőrzés nemzetmentő küldetéses szerepének, amely a múlt század hatvanas-hetvenes éveiben meghatározta az erdélyi/romániai magyar irodalmat. Mindezt nem deklaratíve, hangzatosan (és magasztosan) tette, hanem (az általa választott) nyelv által, az írásokban megalkotott szövegvilág révén. Ezt a mítosztalanító eljárást folytatta a Sinistra körzetben (Bodor 1992), Az érsek látogatásában (Bodor 1999), a Verhovina madaraiban (Bodor 2012), és némileg a Seholban (Bodor 2019), az identitások viszonylagosításával, azok határhelyzeti meghatározottságának, valamint az álküldetéses történeteknek a tematizálásával. Arról, hogy az őt 
követő, a prózaszövegeikben Erdélyt re-konstruáló prózaírók hogy folytatják ezt a mítosztalanítást, már rengetegszer beszéltem/írtam: Dragomán György, Tompa Andrea, Vida Gábor, Láng Zsolt, Papp Sándor Zsigmond stb. írásairól van szó (Lásd Bányai 2011).

2.

„Majd mindenkinek mást mondok” (Bodor 1992: 22), válaszolja Andrej Bodor Nikifor Tescovinának a Sinistra körzet második, névadó/beavató fejezetében, amikor a helyi körzetrend(szer)be való beilleszkedés tematizálódik. Ez a frázis ugyanakkor kitágítható: Bodor Ádám világ- és szövegszemléletére, valamint írásmódjára is utal. Egyrészt az olvasás/értelmezés/interpretáció sokféleségét, határtalanságát biztosítja (erre a legjobb példa, hogy a szövegek megengedik a referenciális, „helyhez kötött” olvasást, de attól el is vonatkoztatnak), másrészt a folyamatos viszonylagosítás, az eldönthetetlenség, a meghatározhatatlanságok és többértelmüségek miatt a szöveg uralhatatlansága kerül fókuszba.

A Bodor-próza egyik alapvető karakterisztikuma a határonlét. Ezt egyrészt a kulturális köztesség, a nyelvköziség, a másság/idegenség tapasztalat és a nevek alkotta rendszer biztosítja, másrészt a regények (de egyes novellák) tere is határvidéket alkot: a Sinistra körzet a szövegbeli utalások alapján az ukrán határ mellett topografizálható, Az érsek látogatásának fö helyszíne, Bogdanski Dolina konkrétan határváros, a Verhovina madarai című regény helyszíne, Verhovina pedig valahol, valamilyen határon túl van. A Sehol meg már címében is jelzi: a „túliságot” is megkérdőjelezve lebeg a prózatér határvonalán.

Az eddig megjelent Bodor-regények trilógiakénti összeolvasása révén a keletközép-európai rendszerváltás-narratívák elvont, elvonatkoztatott paradigmája képződik meg. Ha a Sinistra körzetet a totalitarizmus elbeszéléseként, Az érsek látogatását az átmenet narratívájaként, a Verhovina madarait pedig a túliság reprezentációjaként értelmezzük, e három regény mindezeket a hatalmi viszonyok teresüléseként tárja elénk (Lásd Bányai 2012). 
A Sinistra körzet hatalmi struktúrájának tetején látszólag az ezredesek állnak, de egyrészt belőlük is számtalan van, másrészt őket is ide-oda helyezi egy felettes hatalmi rendszer, aminek a léte és természete ugyan kiismerhetetlen, de ugyanakkor megkérdőjelezhetetlen. Minden és mindenki ennek rendelődik alá, és a túlélésre rendezkedik be. „Kezdetben hányni fogsz tőle, de aztán megszokod. / Biztos" (Bodor, 1992: 23) - hangzik el a regény elején, Andrej Bodor körzetbe érkezésekor a denaturált szesz ivására vonatkozóan; emlékszünk: faszénen átszürve a legjobb, esetleg kenyérbélen, szivacsos gombán vagy törött áfonyán, pettyes tárnicsgyökeret is lehet áztatni benne, de mindezek hiányában egy darab kapca is megfelel, találékony népség a sinistrai. Hiszen ez vált az életükké, kedvelt italukká, mert más nem is volt, s mert a túlélés vált napi életcéllá. A totalitárius rendszer is ekképp válik domesztikálttá: kezdetben hány tőle az ember, de aztán - megízesítve és megszürve, saját koktéllá keverve - megszokja. Ennélfogva mindannyian előbb vagy utóbb belekeverednek valamibe. Miként Andrej Bodor is, Sinistrára érkezésekor. Bár a Bodor-próza jellemzően atemporális, az időre vonatkozó jelzések esetlegesek és kauzalitás híján vannak, legfőképp a „két héttel azelött” formula érvényes, öt évvel a Sinistra körzetbe érkezése után (Bodor, 1992: 67), Andrej Bodor célját részlegesen elérve, találkozva a rezervátumban fogadott fiával, Béla Bundasiannal, ez utóbbi figyelmezteti is erre: „Hiszen most már maga is közéjük tartozik. Másként nem lehetne itt” (Bodor 1992: 77). A „közéjük” tág fogalom, a hatalom részeseinek és alárendeltjeinek, a „valamibe való belekeveredettek" halmaza, annak képlékenységével, ellenőrzöttségével, kiszolgáltatottságával és bizonytalanságával együtt. Nyelvileg körülírhatatlan a „mibe”, mint ahogy a „valami/valaki” névmás is a megfoghatatlan, a más(ik) voltát kérdőjelezi meg.

Mindhárom regény (röviden: Sinistra, Érsek, Verhovina) alaptörténetéhez hozzátartozik a valamibe való belekeveredés és annak kikerülhetetlenségének, elodázhatatlanságának élménye. A belekeveredés indukálja a rendszeren belüliséget, a belülre kerülést. A valamibe belekeveredett személyek nem uralják a maguk alkotta tetteket, nem lévén individuális szabadságuk, saját történeteik 
fölött nem tevődik fel a felelősség morális kérdése sem. Andrej Bodor körzeti látogatásának a célja (a kalandvágyon kívül) fogadott fiának megtalálása, de a körzet ki nem mondott, elhallgatott, viszont érvényes szabályainak megfelelően végre kell hajtania a szabályszegők likvidálását, tehát gyilkosságsorozatba keveredik. Az Érsek (egymást váltogató) narrátorai sem mentesülnek a hatalommal való kényszerü, de elfogadott kollaboráció alól, Anatol Korkodus, a Verhovina egyik fö szereplője már azt se tudja, kivel kollaborál, a végén mégis belehal. A belekeveredés együttmüködést feltételez, a rendszerhez való odatartozást. A hatalmi viszonyok teresülnek: a tér által létrehozott viszonyrendszerben a hosszas szivárgás, beleivódás révén valamilyen szinten mindenki a hatalmi rendszer részévé válik: létrehozó, hordozó vagy alávetett pozícióban. Ezért is differenciálatlan a sinistrai hatalomtér: nem osztható áldozatokra és hóhérokra, mindenki valamilyen szinten rendszeráldozat, illetve saját maga és mások hóhéra.

A Sinistrában az érzékelhető hierarchia különböző fokain elhelyezkedő egyének, csoportok közötti diskurzus a hatalom által diktált feltételek között zajlik: a hatalom által meghatározott emberek a rend részeseivé s ezáltal a rendszer nyelvének használóivá válnak. A nyelv nélküli, nyelvtelen, marginalizált emberek csak a hatalom által uralt és diktált szikár, bürokratikus, álságos, formalizált, közhelyekkel tűzdelt nyelvén képesek megszólalni. Ám ez a nyelvhasználat olykor átcsap ironikus megszólalásba vagy a megszólalás megtagadásába, ami jelzi, hogy a hatalmi diskurzus sem képes teljes ellenőrzöttség alatt tartani a körzeti világot. Van valamiféle kölcsönös egymásrautaltság a hatalmi rendszer és kiszolgálói között, hiszen a hatalmi diskurzus nem lenne érvényes a neki kiszolgáltatott (és az őt kiszolgáló) réteg léte nélkül (Lásd Bányai 2012).

Bogdanszki Dolina, az Érsek várostere folyamatos hatalomátvételek között van. A legelső - a helység további sorsát meghatározó esemény - 1920-ban történt (a regény legpontosabb időmegjelölése ez), és a határfolyó, a Medvegyica medrének megváltozásához köthető: „egy kiadós esőzés után egy éjszaka nem zúgva, bőgve, hanem csöndben és alattomban áttörte a gátakat. Attól az éjszakától 
kezdve nem északról, hanem délről kerülte meg a várost. [...] Bogdanski Dolina [...] egyszerüen átkerült a túlsó partra. Egy másik országba" (Bodor 1999: 19). Azóta az állandó bủz uralja a várost (ne feledjük: a Sinistra körzetnek is jellegzetes szaga volt!), valamint a kámzsások tartják hatalmuk alatt: a hegyivadászokból szerzetesek, tiraszpoli kutyások, az ezredesekből érsekek, archimandriták, szakállas pópák váltak: a hatalmi szimbólum az Érsekben a csuha és a szakáll lesz. A hatalmi rendszer alapjai változatlanok, továbbra is a Sinistra-beli „mindenki mindent tud" elve uralkodik, az alattvalók a hatalmasságok kiszolgáltatottjai, amelyet természetesen türnek, és természetesen várják a soha meg nem érkező érseket. Az átmeneti korszakok, a különböző rendszerváltozások megidézésével a hatalomváltás látványos - a maszkok, álarcok révén -, de lényegében változatlan rendszerben müködik tovább.

A verhovinai hatalom viszont sokkal nyúlékonyabb, átláthatatlanabb: látens, csak sejthető, ugyanakkor fenyegető: Verhovina téridejében az állandó félelem, a gyanakvás és a megérzés hatalma dominál, és zsigeri rettegés a változástól. A korábbi regényekhez viszonyítva kevésbé válik külön a megfigyeltek és a megfigyelők viszonya: olykor egybemosódik az alávetettség és kiszolgáltatottság különböző szintjeinek az ismérve. A rendszer - ismeretlenségéböl és kiismerhetetlenségéből adódóan is - kegyetlenebb, agresszívebb a korábbiaknál, s mindez a szöveg nyelvi megformáltságára is érvényes. Verhovina lakói önmaguk foglyai is: bár kiléphetnének e kegyetlen hatalomtérböl, nem élnek a szabadságukkal (a korábbi regények szereplői ezt nem tehették meg, mozgásuk korlátozott keretek között zajlott). A verhovinai polifón (lásd Korpa-Porczió 2012), egymással versengésben levő hatalmi rendszerek a korábbi (sinistrai és Bogdanski Dolina-i) rendszerek tapasztalati és emlékezeti hálójából képződnek meg, de azon túl is mutatnak: a verhovinai erőszaknyelv brutálisabb, kegyetlenebb a korábbi Bodornyelvhez képest, mely szintén a túliságot hivatott jelezni.

A Sehol (Bodor 2019), eleddig a legfrissebben megjelent Bodor-novelláskötet pedig a korábbi Bodor-összes frivol, ironikus, olykor cinikus, parodisztikus, de a humort se nélkülözö recepteskönyve. Amely önreflexív betekintést enged a szikár, 
letisztult (írás)konyhai berendezés és a (próza)összetevők világába, felkínálja a látványkonyha alapelemeinek a vizslatását, a füszerhintés technikájának ellesését, hiszen korábbi olvasmányainkból tudjuk, Bodor Ádám kiváló szakács, de az, hogy az elkészült étel hogyan kerül a fogyasztó bendőjébe, sikerül-e megemésztenie, sőt, a kritikusok és a tanulmányírók véleménye, tehát a hatástörténet helyzete, az vagy kikerül a látókörböl, vagy kritika alá helyezödik (1. Bányai 2019).

A Sehol történeteinek cinikus, parodisztikus a hangneme, amely alapösszetevője, szövegszervező ereje a kötetnek. A prózanyelv a mai mindennapi közbeszédet konstruálja, írja újra: az életvezetési tanácsoktól, a bürokratikus, semmitmondó adminisztratív álnyelvtől a sekélyes, túlbeszélt üresjáratokig. A nyelvi manipulatív gesztusok leleplezése. De a tudományos nyelv és a tudományosság maga sem mentesül a kifigurázástól: egyrészt az irodalomkritika és -tudomány kerül górcső alá, másrészt maga a tudósféle figura, a rágcsálószakértő alakja is.

A Sehol novelláinak a hősei (vagy antihősei) az örökös, bodoros útonlevést, a(z egy)helyben-járást példázzák, mindenki valamilyen szinten idegen, „gyüttment”, aki állandóan jön-megy, noha az az érzésünk, hogy ki se mozdul, csak magából. De azt is úgy teszi, hogy a legbizarrabb, horrorisztikusabb, antihumánusabb jelenet is elfogadhatóvá váljék: a halál is az élet része, még akkor is, ha egy kamrai fürdődézsában következik be vagy az árnyékszéken, miközben kérdőjellé merevedik a test. A testiség - amely a korábbi kötetekben szintén a hatalom által domináltan mutatkozott, a diktatúra ugyanis a testet is a hatalma alatt tartja - itt jelen való léte erős szövegreferenciákkal bír: ez határozza meg az emberek mindennapjait, illetve a testi szükségletek kielégítésére tett kísérletek. Nemcsak a testük rabjai és kiszolgáltatottjai ezek a marginalizált egyedek, hanem a térnek és a belőle generálható, visszaható viszonyoknak is. Ezekben a szövegekben túl vagyunk a verhovinai rendszertúliságon is: nincs semmiféle hatalmi struktúra, a minden mindegy elve dominál, vagy inkább a lesz valahogy. Még csak meghökkentőnek se nevezném mindezt, annyira ismerős, „természetes” a közeg, a helyzet. 
Már az első novellában lecsúszunk Európa tetejéről a föld alá, a „bányába”, a megfigyelők és megfigyeltek levéltárának alvilágába, az információhatalom tárházába. A mélyben őrzött iratok emberi sorsok átiratai ugyan, amelyek tartalmazhatják az összes, a Sinistrától a Verhovináig felvonultatott egyedekre és a belőlük megképzett világra vonatkozó információhalmazt, de az emlékezet(politika)- és rendszerkutatás fonákságai miatt az egész múltfeltárást is csak ilyen cinikus hangnemben lehet elöadni.

(Ál)tudósi (és konyhai) párhuzamot vonva: a „célszemély” mormotának - a figyelö tekintetek és fotósgép elől menekülve - hátsójából a „rémület kis barna darabkái potyognak az alpesi ködök áztatta havasi fübe. Hehe. Mint a mazsolák Spináth Joli vargabéleséből..." (Bodor 2019: 16). Vagyis szart eredményez minden múltfeltárásra vonatkozó kísérlet, a rendszer „velejéig romlott”, akár a Szüz Macskában feltálalt vargabéles, amely „úgy fest [...], mint a mulandóság komor hírnöke, valami sötét titokkal fénytelen, szikkadt kérge alatt. A metélt rejtekéből néha megtörten kipereg egy-egy szem életunt mazsola" (Bodor 2019: $13)$.

3.

Bodor Ádám írásai kezdetektől fogva kerülték az ideologizálást, a kortárs történésekre vonatkoztatható nyílt párhuzamokat. (Kivételt talán az 1982-ben megjelent A részleg jelent.) A Verhovina madarai mégis túllépett ezen, a polifón, megfoghatatlan, a titkosszolgálatok hatalmi játszmáit is megidéző regény a legerősebb társadalomkritikai műve Bodornak, amely a kurrens, regnáló ideológiákat, a mindenkori politikumot, annak társadalomra kifejtett hatását bírálja. A Sehol ezen is túllép, a rezignált hangnem, a cinikus hozzáállás (vagy épp a „hozzá nem állás”) a lemondás, beletörődés, fásultság időszakának a bekövetkeztét jövendöli, amely teret ad(hat) egy újabb fajta hatalmi rendszer kiépülésének. A Sinistra körzetben egy, a csonttollú madarak által terjesztett járvány, a „tunguz nátha” következményeinek hatalom általi kisajátítása, ellenőrzése, manipulálása került középpontba, a renitensek likvidálása révén (is) 
vált kollaboránssá a (részleges) narrátor, Andrej Bodor. Az Érsekben szintén egy terjengő járvány miatt kerülnek elkülönítőbe azok, akik nem mutatkoznak jó alattvalónak, a Verhovinában is manipulatív eszközökkel bír a beteggé nyilvánítás, karanténba zárás. Nem kevésbé félelmetes az a kép sem, ahogy a hatalom képviselői a Sehol zárónovellájában, a Rebiben „hivatalos emberek” kergetik a pincébe a népet: „Amolyan hatósági jármü, oldalán mindenféle betủkkel és számokkal, fehér mackóruhás, maszkot viselő pofák ülnek benne. A kocsi tetején hangszóró tölcsér, amiböl azt lehet hallani, hogy menjek le a pincébe, torlaszoljam el a bejáratot egy vagy két hordó vízzel, vagy vízzel teli edényekkel, és legjobb, ha kezemmel a tarkómon végigfekszem a földön és nem mozdulok.

Még mit nem" (Bodor 2019: 145).

\section{Bibliográfia}

\section{Kiadások}

Bodor Ádám 1992. Sinistra körzet. Egy regény fejezetei. Budapest: Magvető.

Bodor Ádám 1999. Az érsek látogatása. Budapest: Magvető.

Bodor Ádám 2011. Verhovina madarai. Változatok végnapokra. Budapest: Magvető.

Bodor Ádám 2019. Sehol. Novellák. Budapest: Magvető.

\section{Felhasznált szakirodalom}

Bányai Éva 2011. Térképzetek, névtérképek, határidentitások. Kolozsvár: Komp-Press.

Bányai Éva 2012. Terek és határok. Kolozsvár: Editura Casa Cărții de Știință - RHT Kiadó.

Bányai Éva 2019. A börtönkonyha remekei. Kanyarlátás a Bodorfőztekre. Szépirodalmi Figyelö 4. 91-95.

Korpa Tamás - Porczió Veronika 2012. Verhovina network. Látó 11.

http://www.lato.ro/article.php/Verhovina-network/2491/ (Letöltés dátuma: 2012. 12.15.)

Szirák Péter 2000. A regionalitás és a posztmodern kánon a XX. századi magyar irodalomban. In: Görömbei András (ed.) Nemzetiségi magyar irodalmak az ezredvégen. Debrecen: Kossuth Egyetemi Kiadó. 29-57.

Szolláth Dávid 2019. Fáradt, fanyar önparódia. https://www.es.hu/cikk/2019-05-

17/szollath-david/faradt-fanyar-onparodia.html (Letöltés dátuma: 2019. 09.15.) 


\title{
Variations of Power Constructions in Ádám Bodor's Prose
}

Éva Bányai, University of Bucharest, Faculty of Foreign Languages and Literatures, Institute of Hungarian, Jewish Studies and Romani Studies

\begin{abstract}
In my writing, I examine the variations of power constructions in Ádám Bodor's prose from the Sinistra Zone through the Verhovina madarai (Birds of Verhovina) to Sehol (Nowhere), from the omnipotent power of abstract dictatorship representation to plural, elusive spaces of power. My investigation is not escaped by the power discourse of the transitional spaces formed during Az érsek látogatása (The Visit of the Archbishop), but the latest contemporary viral experience is also discussed.
\end{abstract}

Keywords: contamporary Hungarian prose, Ádám Bodor, power.

\section{Varijante prostora moći u prozi Adama Bodora}

Eva Banjai, Univerzitet u Bukureštu, Fakultet stranih jezika i književnosti, Institut za hungarološke, judaističke i romske studije

\section{Sažetak}

U svom radu ispitujem kakve su to varijacije konstrukcija moći u prozi Adama Bodora, od Sinistre preko Ptica Verhovine do Nigde, od svemoći apstraktnog prikaza diktature do pluralne, na svim poljima neuhvatljive, pod kožom skrivene i kroz svaku poru prodiruće moći. Analizom sam obuhvatila i diskurs moći tranzitivnih prostora, formiran u knjizi Poseta arhiepiskopa, ali će takođe biti reči i o najnovijim iskustvima s virusom.

Ključne reči: savremena mađarska proza, Adam Bodor, moć. 